\title{
PASSIVE REMEDIATION OF CHLORINATED VOLATILE ORGANIC COMPOUNDS USING BAROMETRIC PUMPING
}

by

\author{
Joe Rossabi
}

Westinghouse Savannah River Company

Savannah River Site

Aiken, South Carolina 29808
B. B. Looney
C. A. Eddy Dilck
B. Rina
V. J. Rohay

This paper was prepared in connection with work done under the above contract number with the U. S.

Department of Energy. By acceptance of this paper, the publisher and/or recipient acknowledges the U. S. Government's right to retain a nonexclusive, royalty-free license in and to any copyright covering this paper, along with the right to reproduce and to authorize others to reproduce all or part of the copyrighted paper. 


\section{DISCLAIMER}

This report was prepared as an account of work sponsored by an agency of the United States Government. Neither the United States Government nor any agency thereot, nor any of their employees, makes any warranty, express or implied, or assuines any legal liability or responsibility for the accuracy. completeness, or usefulness of any information, apparatus, product, or process disclosed, or represents that its use would not infringe privately owned rights. Reference herein to any specific commercial product, process, or service by trade name, trademark, manufacturer, or otherwise does not necessarily constitute or imply its endorsement, recommendation, or favoring by the United States Government or any agency thereof. The views and opinions of authors expressed herein do not necessarily state or reflect those of the United States -Government or any agency thereof.

This report has been reproduced directly from the best available copy.

Available to DOE and DOE contractors from the Office of Scientific and Technical Information, P. O. Box 62, Oak Ridge, TN 37831; prices available from (615) 576.8401 .

Available to the public from the National Technical Information Service, U. S. Deparment of Commerce, 5285 Port Royal Rd., Springfield, VA 22161 


\title{
PASSIVE REMEDIATION OF CHLORINATED VOLATILE ORGANIC COMPOUNDS USING BAROMETRIC PUMPING
}

\author{
J. Rossabi, Westinghouse Savannah River Company \\ Bldg. 773-42A, Aiken, SC 29808
}

(803)725-5220

\section{B. B. Looney, Westinghouse Savannah River Company}

\author{
C. A. Eddy Dilek, Westinghouse Savannah River Company \\ B. Riha, ORISE, Westinghouse Savannah River Company \\ V. J. Rohay, Westinghouse Hanford Company
}

\begin{abstract}
The purpose of the Savannah River Integrated Demonstration Program, sponsored by the Department of Energy, is to demonstrate new subsurface characterization, monitoring, and remediation technologies. The interbedded clay and sand layers at the Integrated Demonstration Site (IDS) are contaminated with chlorinated volatile organic compounds (CVOCs). Characterization studies show that the bulk of the contamination is located in the approximately $40 \mathrm{~m}$ thick vadose zone. The most successful strategy for removing contaminants of this type from this environment is vapor extraction alone or in combination with other methods such as air sparging or enhanced bioremediation. Preliminary work at the IDS has indicated that natural pressure differences between surface and subsurface air caused by surface barometric fluctuations can produce enough gas flow to make barometric pumping a viable method for subsurface remediation.
\end{abstract}

Air flow and pressure were measured in wells that are across three stratigraphic intervals in the vadose zone. The subsurface pressures were correlated to surface pressure fluctuations but were damped and lagging in phase corresponding to depth and stratum permeability. Piezometer wells screened at lower elevations exhibited a greater phase lag and damping than wells screened at higher elevations where the pressure wave from barometric fluctuations passes through a smaller number of low permeable layers. The phase lag between surface and subsurface pressures results in significant fluxes through these wells. The resultant air flows through the subsurface impacts CVOC fate and transport. With the appropriate controls (e.g. solenoid valves) a naturally driven vapor extraction system can be implemented requiring negligible operating costs yet capable of a large CVOC removal rate (as much as $1-2 \mathrm{~kg} /$ day in each well at the IDS).

Introduction

\section{Surface/Subsurface Air Pressure and Flow}

The observation of the effects of atmospheric pressure fluctuations on subsurface flows dates back to early observations of weather changes. The flow of air into and out of cave entrances with numerous subterranean passages, particularly before storm events when rapid barometric pressure changes 
occur, is observable throughout the world. This barometric effect and its implications for chemical transport is mentioned in a 1904 monograph describing the release of carbonic acid from soil and its replacement with oxygen from the subsurface in response to atmospheric pressure changes (Buckingham, 1904). The monograph describes a soil rinsing effect that occurs because of barometric changes and mentions that the response of subsurface air pressure changes should be damped and lagged with respect to surface pressure changes. The amount of damping and time lag should increase with increased depth. The author tried to estimate the depth of penetration of "barometric waves" using average soil temperatures, porosities, depth to impermeable strata, and observed time series data of surface barometric pressure in three different geographical locations in the midwestern, southern, and northeastern portions of the United States. Unfortunately the sensitivity of the method and modeling boundary assumptions of the author (e.g., a sharp dividing line between surface and subsurface air) led to the erroneous conclusion that barometric pressure fluctuations cause a maximum subsurface penetration of approximately $0.5 \mathrm{~m}$ and that diffusion dominates the barometric effect in chemical transport in the subsurface. The article is worthy of note because of its attempt to quantify the barometric effect.

Several investigators have rejected the barometric effect as insignificant in transport of volatile contaminants in the subsurface (Sleep and Sykes, 1989; Weber and Schwille, 1991). Nevertheless, a growing body of historical and recent literature supports the role of barometric pressure changes in influencing subsurface systems. Researchers found that the barometric effect and other natural forces, such as tidal forces, have a significant impact on subsurface hydrostatics as observed in water level fluctuations in wells (Clark, 1967), as well as the dynamics of fluid flow in the saturated zone (Peck, 1960; Weeks, 1978, 1979; Rojstaczer, 1988; Rojstaczer and Riley, 1990; Ritzi et al., 1991). Ritzi et al.(1991) examined the viability of using the observed water level response as a result of atmospherics and earth tide forces to determine aquifer properties. Using a spectral method to determine the well response to these natural forces, the authors successfully derived the transmissivity values for an aquifer. In their paper they found the atmospheric effect to have a larger impact on well response than earth tide effects.

Although barometric pressure fluctuations have been used in hydrogeologic investigations such as determining aquifer parameters, until recently, the few researchers that have considered the barometric effect an important chemical transport mechanism have been predominantly those studying radon movement through the soil (Clements and Wilkening, 1974; Owczarski et al., 1990) and into structures (Narasimhan et al., 1990; Tsang and Narasimhan, 1992; Garbesi et al., 1993) and radiation transport in fractured rock (Nilson et al., 1991). Lately, though, some work has been done on the relation between surface/subsurface pressure gradients and volatile organic contaminant movement (Little et al., 1992; Massman, 1992; Rohay et al.,1992; Rossabi et al., 1992; Pirkle et al., 1992; Forbes et al., 1993). These researchers have found that the barometric effects observed by Buckingham are of far greater magnitude and importance than he suspected.

At the Savannah River Site (SRS), significant fluxes of contaminants out of vadose zone wells have been observed in response to barometric pressure drops. With an understanding of the dynamics of the subsurface response at different strata to surface fluctuations, and engineering access (e.g., vadose zone wells) to the appropriate contaminated zones, an effective, low cost contaminant removal system can be designed. 


\section{Site Description}

SRS encompasses an 800 square-km area near Aiken, South Carolina and is located on the upper Atlantic Coastal Plain. The site is underlain by a thick wedge (approximately $300 \mathrm{~m}$ ) of unconsolidated Tertivry and Cretaceous sediments which overlay the basement consisting of preCambrian and Paleozoic metamorphic rocks and consolidated Triassic sediments (siltstones and sandstones). The Cretaceous and younger sedimentary section consists predominantly of sands, clayey sands, and sandy clays (Eddy et al, 1991).

Groundwater flow at the site is controlled by hydrologic boundaries: flow at and immediately below the water table is to local tributaries, whereas flow in the lower Tertiary aquifer is to the Savannah River or one of its major tributaries, and flow in the Cretaceous aquifers is toward the Savannah River. Flow in the shallow aquifers in the immediate vicinity of the site used in these experiments is highly influenced by the eleven well pump-and-treat recovery network (Kaback et al., 1991). This network pumps approximately $2300 \mathrm{lpm}$ to an air stripper which effectively removes the solvent from the aqueous stream.

The DOE-owned area contains a nuclear material production facility in operation since 1951. SRS released various chemicals into the environment during its operation, resulting in several areas of soil and groundwater contamination. The largest subsurface contaminant plume resulted from releases of chlorinated volatile organic compounds (CVOCs). SRS used trichloroethylene (TCE) and tetrachloroethylene (PCE) until the early 1980s as metal degreasing solvents. Elevated levels of these compounds have been measured in the groundwater at several locations onsite . Conventional groundwater pump-and-treat systems have been installed in two areas on the site but this type of system does not effectively remediate contamination in the vadose zone where a large fraction of the contaminants reside.

\section{Savannah River IDS Description}

The Department of Energy's Office of Technology Development initiated an Integrated Demonstration Program at SRS in 1989. The objective of this program has been to develop, demonstrate, and evaluate innovative technologies which can improve present-day environmental restoration methodologies. The Integrated Demonstration Program at the SRS is entitled "Cleanup of Organics in Soils and Groundwater at Non-Arid Sites." New technologies in the areas of drilling, characterization, monitoring, and remediation have been demonstrated and evaluated in comparison with baseline technologies for their technical performance and cost effectiveness.

The area selected for the Savannah River Integrated Demonstration Site (SRIDS) is along an abandoned process sewer line that carried non radioactive solvent waste to a seepage basin for 27 years beginning in 1958. Characterization data indicated that several leaks existed in the sewer line (ca 6-m depth) which served as localized sources of contamination. Its use was discontinued in 1985. Over two million pounds of solvent are estimated to be in the subsurface in the vicinity of the demonstration site (Looney, 1992). Two horizontal wells were installed at the site at depths of approximately $49 \mathrm{~m}$ and $23 \mathrm{~m}$ as part of the Integrated Demonstration Program. The lower well is designed for gas injection below the water table (ca $41-\mathrm{m}$ depth), and the upper well is used for vapor extraction. An in situ air stripping experiment, resulting in the removal of $7260 \mathrm{~kg}$ of solvent, 
was performed for twenty weeks in 1990 using these wells. An in situ bioremediation experiment was recently completed at the site. Air with small concentrations of methane was injected into the subsurface to stimulate biodegradation of the contaminants by methanotrophic bacteria. The results from this test are being analyzed. Five additional horizontal wells have recently been installed in the area.

Many clusters of monitoring wells were installed at the SRIDS. Each water well cluster consists of two wells, one screened in the water table, one screened in the upper sand of the Tertiary aquifer. The vadose zone well clusters consist of three piezometer wells with five foot screen lengths at different depths targeting the edges of the major clay zones at the site. Several other fully screened vadose zone wells were also installed at the site. Many continuously cored boreholes have been drilled to the water table or deeper and logged. Samples for chemical and microbiological analyses were collected from the cores and used to characterize the site. Geophysical logs of the deepest boreholes $(58 \mathrm{~m})$ were used to create geologic cross sections. A gross cross-section of the geology at the SRIDS is shown in Figure 1.

\section{Methodology}

Surface and subsurface pressures in several vadose zone wells at different depths and locations were continuously monitored for over one year at the Savannah River Site. These data consisted of measurements taken at a frequency of $0.1 \mathrm{~Hz}$, (averaged and stored every 10 minutes) with pressure transducers (Vaisala, model PTA427) mounted in an enclosure at the wellhead. The data from these transducers were stored on dataloggers (Campbell $21 \mathrm{X}$ micrologger) maintained in an enclosure near the wellhead and periodically downloaded for analysis. The 10 minute averaging time precluded the analysis of small magnitude, high frequency effects that have been observed and are due to local pressure variations. These may be significant for near surface flows and will be studied in future work. The main objective in this work was to examine lower frequency and aperiodic events caused by diurnal temperature variations and weather changes.

The pressure transducers were connected to the stems of $2.5-\mathrm{cm}$ diameter PVC piezometers. These piezometers had a screen length of approximately $1.5 \mathrm{~m}$ and were clustered in groups of three at different depths corresponding to the principal clay zones found in the vadose zone at this location. The holes for the piezometers were drilled by hollow stem auger and the different depths were separated by bentonite and grout. Construction diagrams of these wells are shown in Figure 2. The pressure transducers were tested against each other and final results were corrected for differing offsets (less than $0.5 \mathrm{mB}$ difference). Hysteresis differences between the transducers were found to be negligible. The piezometers were terminated in a $0.635-\mathrm{cm}^{\text {Swagelock }}{ }^{\mathrm{TM}}$ female quick-connect (normally closed). The transducers were fitted with a short length of tube (less than $30 \mathrm{~cm}$ ) attached to a $0.635-\mathrm{cm}$ Swagelock ${ }^{\mathrm{TM}}$ male quick connect. The well stems, transducers, and plumbing were shielded from the sun to reduce temperature induced pressure changes in the tubing at the surface. Five clusters of three piezometers each were monitored at different times.

Flow out of the wells was measured with mass flow meters (Omega Model FMA5600) or a hot wire anemometer (Sierra Instruments, Inc. Model 600 V1-PS-EO-43). The mass flow meter was connected to the well by high density polyethylene tubing $(1-\mathrm{cm}$ diameter). Pressure was not measured in the well being monitored for flow. Pressures in that well were assumed to be similar to 


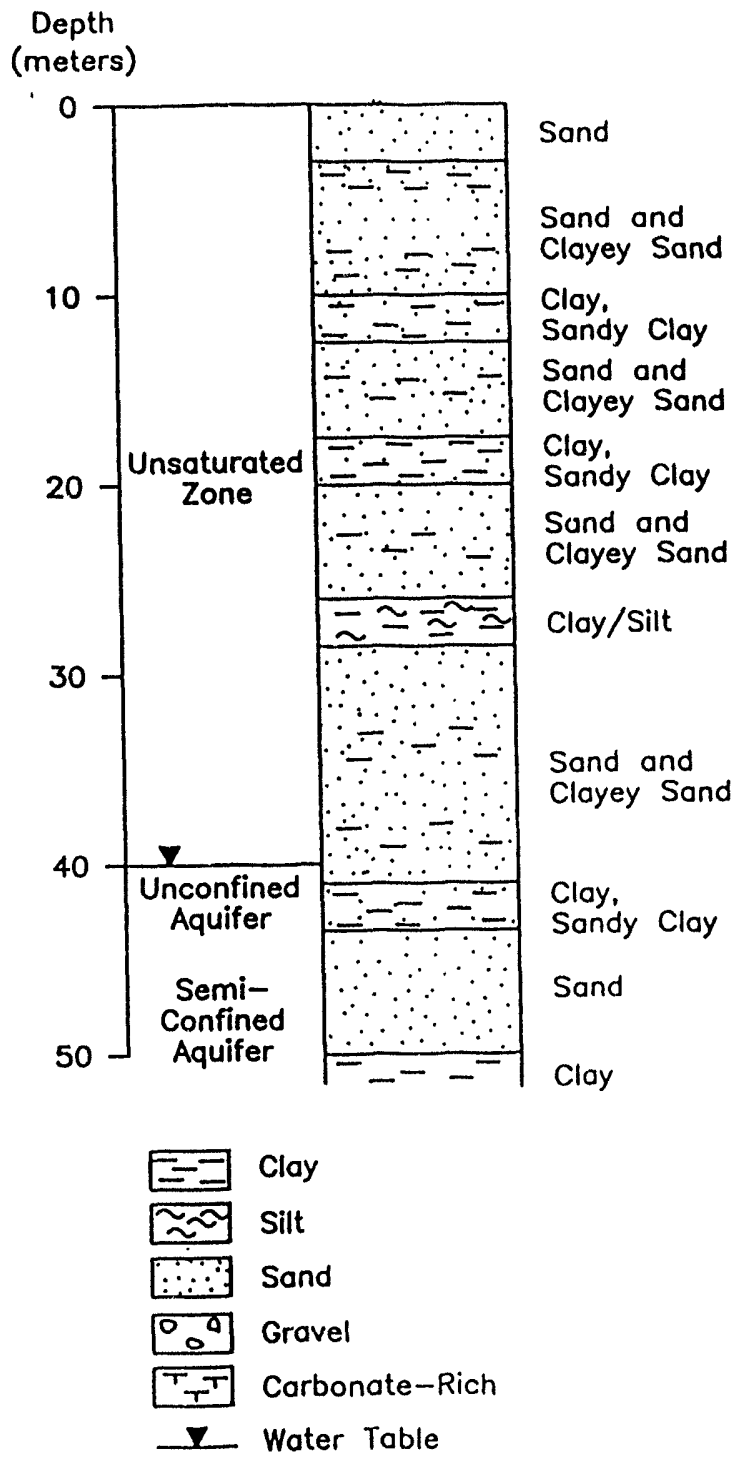

Figure 1. Gross cross-section of the geology at the SRIDS.

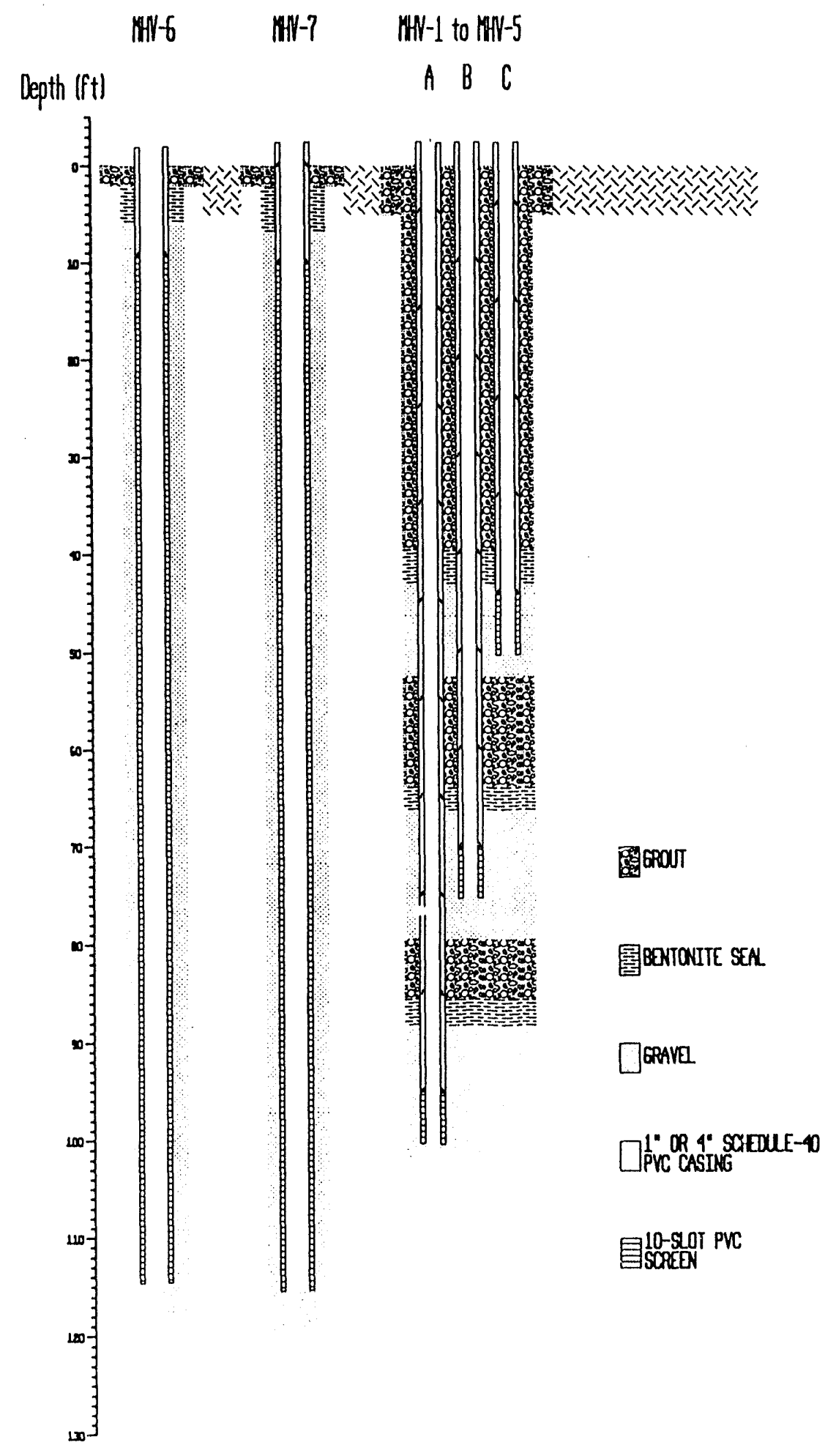

Figure 2. Construction diagram of vadose zone wells at the SRIDS. 
pressures in nearby wells of similar construction. The hot wire anemometer was used to measure flow in a $10-\mathrm{cm}$ diameter PVC well in the vicinity of the $2.5-\mathrm{cm}$ diameter PVC wells. The larger well was fully screened in the vadose zone and therefore depth-discrete pressure measurements were not possible in this well. Flows in the well corresponded to the pressure gradients observed in a 2.5 $\mathrm{cm}$ piezometer nearby.

\section{Results}

The surface and subsurface pressure measurements indicate a response difference of the piezometer pressure to surface pressure fluctuations corresponding to depth. Continuous pressure profiles covering 24 days are shown in Figure 3. The first half of the graph, up to 11/17/93, shows the response from diurnal barometric cycles. In this time period, daily atmospheric pressure fluctuations produce a corresponding daily response in the piezometer wells. The daily average of the individual pressures remain relatively constant over the time period. The second section shows the response to weather fronts moving through the region. In this section, a low pressure front has moved into the area beginning on $11 / 17 / 93$. The pressure reaches a minimum on $11 / 20 / 93$ and climbs rapidly on $11 / 20 / 93$. Similar weather patterns follow.

Although the pressure response in all three wells is clearly related to the surface pressure, the types of the responses differ in the wells. The shallower piezometer (MHV1c) closely tracked the surface pressure fluctuations. In MHV1c, a slight time lag was evident (approximately 60 minutes) but the significant features of thr barometric pressure continuum were maintained.

The response of the $d_{\text {i }}$ per piezometers (MHV1a,b) to surface pressures are dramatically different. The damping of the pressure amplitude in these piezometers minimizes the diurnal and higher frequency pressure signal observed in the atmospheric pressure trace. The major response of these piezometers is to the slower surface pressure fluctuations predominately driven by weather fronts. The lagged response is evident in this graph but can be clarified by looking at a 12 hour smoothed plot of the data in Figure 4. Data smoothing is accomplished by taking a running average of the data over the time period of interest. Figure 5 demonstrates the correlation between the two pressure profiles. A value for the time lagging can be obtained by examining the data in parallel using the correlation function with the correlation coefficient, $\rho_{x y}$ defined by:

$$
\rho_{x y}=\frac{\frac{1}{n} \sum_{i=1}^{n}\left(X_{i}-\mu_{x}\right)\left(Y_{i}-\mu_{y}\right)}{\sigma_{x} \sigma_{y}}
$$

where $\mathrm{n}$ is the number of data points, $\mathrm{X}_{\mathrm{i}}$ are the surface barometric pressure data through time; $\mathrm{Y}_{\mathrm{i}}$ are the lagged well pressure data through time; $\mu_{x}, \sigma_{x}$ and $\mu_{y}, \sigma_{y}$ are the mean and standard deviation of the two pressure sets respectively. For each assumed lag time, the best correlations will be associated with the best estimate of lag time (highest correlation coefficient). From this treatment, the time lag of the piezometer screened at the lowest elevation (MHV1a) is determined to be approximately 705 minutes. The time lag of the piezometer screened at the next higher elevation, MHV1b, is slightly snialler than MHV1a. This is consistent with the fact that MHV1b passes 


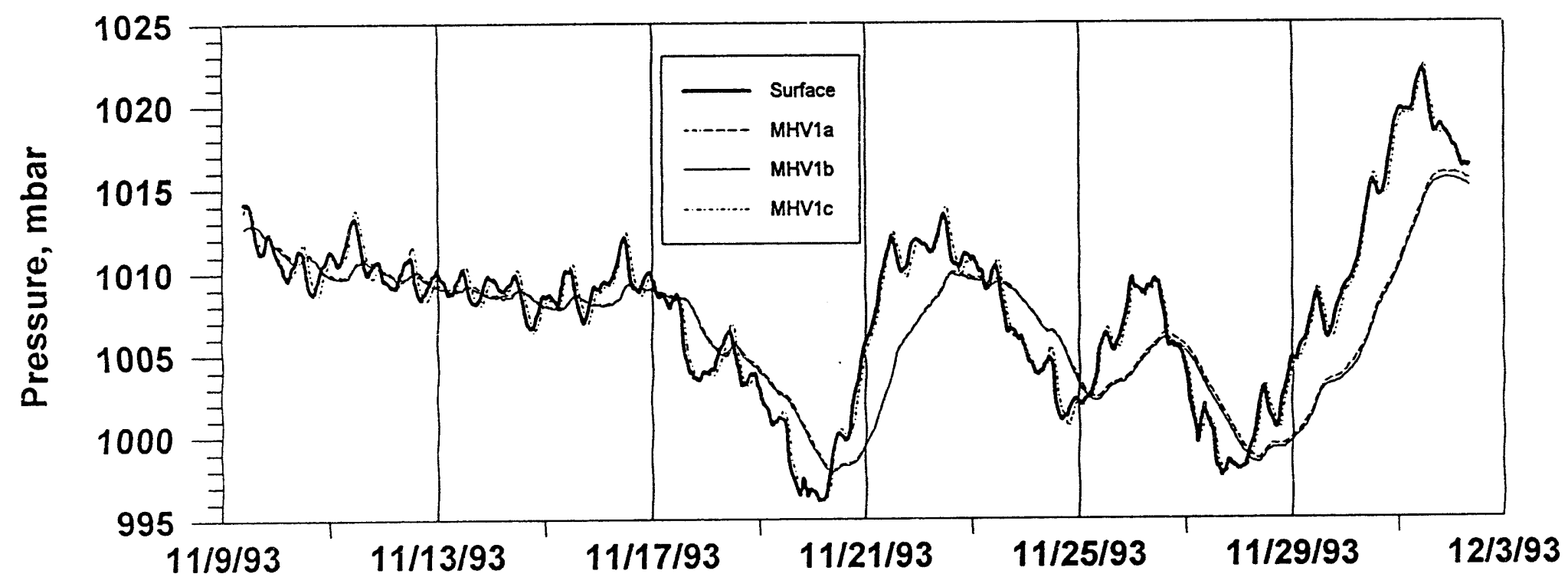

Figure 3. Barometric pressure and the corresponding pressure profiles in three vadose zone wells.

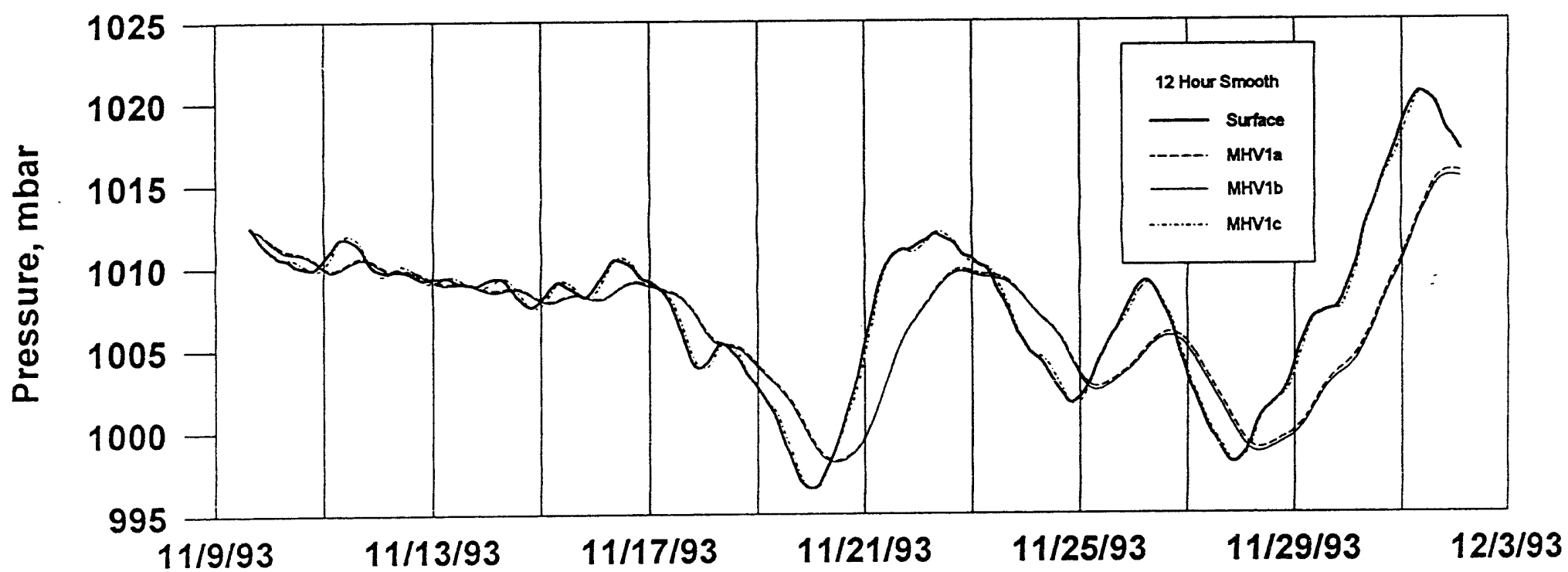

Figure 4. Smoothed pressure profiles using a 12-hour running average. 
through a smaller number of lower permeability layers than does MHV1a. It is also important to note the smaller amplitude of the pressure fluctuations in MHV1a and MHV1b. This damping, like the time lag, is due to the cumulative effect of the lower permeability layers on the air pressure wave initiated at the surface.

Figure 6 illustrates the air flow resulting from pressure differences between the surface and subsurface. Positive air flow represents flow from the subsurface to the surface and negative air flow indicates flow from the surface into the well. Air blows out of MHV6 whenever the subsurface pressure is greater than the surface pressure. In this figure, the pressure in MHV4a is representative of the pressure found in MHV6.

\section{Discussion}

From the data depicted in Figure 3, MHV1a and MHV1b are exhaling approximately $50 \%$ of the time. To minimize the dilution and dispersion of the subsurface contaminants that would be associated with well inhaling, it would be prudent to prevent air flow from the surface into the well by sealing the well during the times of relatively high surface barometric pressure. A valve controlled by a differential pressure switch can be used to allow flow out but preclude flow in.

Flow rates observed in wells during exhalation have been as high as $90 \mathrm{lpm}$. Many of our wells have concentrations exceeding $1000 \mathrm{ppmv}$ in the offgas. This implies a removal rate of approximately $1.0 \mathrm{~kg}$ /day by this passive method. Although this is $1-2$ orders of magnitude below the removal rate of an active vapor extraction system, the operation and maintenance costs of the passive system make it an appropriate technology for both interim action, because of the ease and rapidity with which the system can be implemented, for small sites that pose little risk, and for long term remediation, i.e. when the active extraction system reaches the point of diminishing returns due to mass transfer limitations.

The issue of cost is important in the determination of remediation strategies. If a system needs to operate until pristine conditions are recovered, remediation systems that have significant power or operation and maintenance requirements can become prohibitively expensive because of the long period of time normally required to attain that cleanup level. Because the driving force of the barometric pumping removal system is supplied naturally, the only costs for the operation and maintenance of this system are power for the valve and differential pressure control system. These can be run on batteries charged by solar cells. Well head treatment using carbon collection is compatible with both the flow rates and mass removal rates observed to date. Other offgas treatment strategies are also possible because of the relatively low flux rates of this system. For minimal cost, this system can operate for the extended times required to attain pristine conditions.

\section{Conclusions}

Subsurface pressures were measured through time at different depths and compared with the surface barometric profile. A phase lagged and amplitude damped response was observed in the wells dependent on their depth. This effect is related to the cumulative number of low permeability zones between the well's screened zone and the surface. The pressure gradients induced by this phenomena can be used to produce sustained flows from the subsurface to the surface. In areas where the subsurface contains 


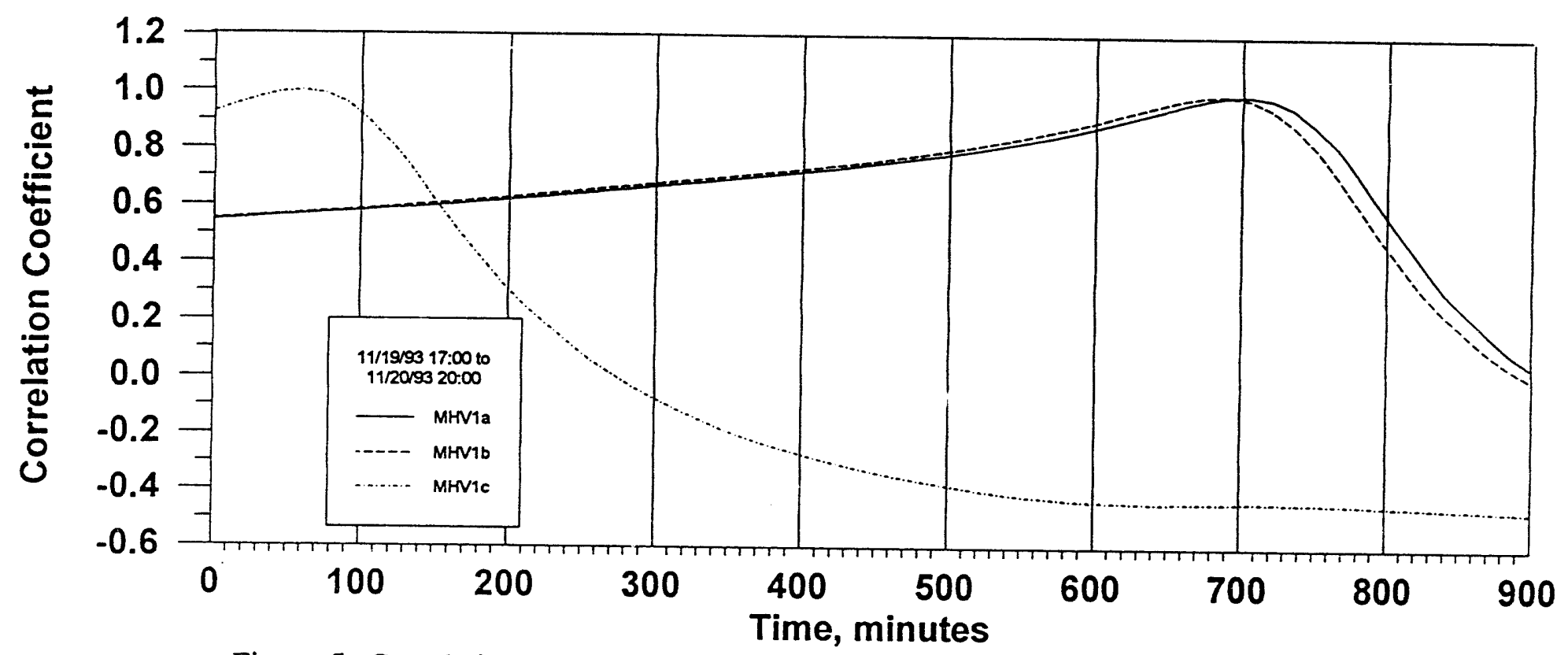

Figure 5. Correlation coefficient vs lag time with respect to surface pressure of the three wells.

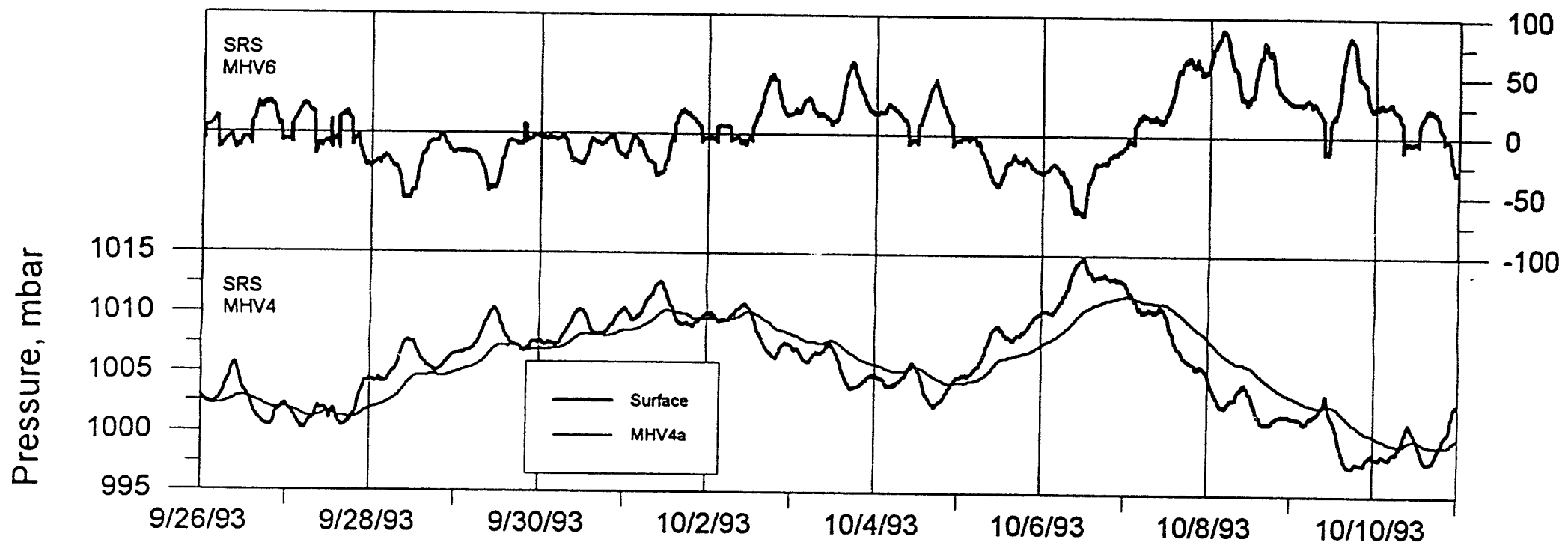

Figure 6. MHV6 air flow and MHV4a pressure vs surface pressure. 
volatile contaminants, the flows induced by the pressure gradients will carry these contaminants out of the subsurface. This naturally driven contaminant removal system can be used to effect a remediation at a minimal cost. Further work is needed to determine the dynamics of the surface/subsurface pressure relationship to optimize the barometric pumping system.

\section{Acknowledgments}

The authors acknowledge the valuable contributions of Jennifer D. Schramm (Purdue), Brian Peters (Ebasco Services, Inc.) and the formation of a Barometric Pumping Consortium consisting of researchers from Westinghouse Hanford Company, Battelle Pacific Northwest Laboratory, Lawrence Livermore National Laboratory, Los Alamos National Laboratory, Idaho National Engineering Laboratory, and Westinghouse Savannah River Company as part of the DOE sponsored Arid Sites Integrated Demonstration Program. The information contained in this article was developed during the course of work under Contract No. DE-AC09-89SR18035 with the U.S. Department of Energy. By acceptance of this paper, the publisher acknowledges the U.S. Government's right to retain a nonexclusive, royaltyfree license in and to any copyright covering this paper along with the right to reproduce, and to authorize others to reproduce all or part of the copyrighted paper.

\section{References}

Buckingham, E. (1904) Contributions to our knowledge of the aeration of soils. U.S. Department of Agriculture Bureau of Soils Bulletin, 25, 7.

Clark, W. E. (1967) Computing the barometric efficiency of a well. Journal of Hydraulics Division. Proceedings of the American Society of Civil Engineers, HY4, 93.

Clements, W. E. and Wilkening, M. H. (1974) Atmospheric pressure effects on Rn-222 transport across the earth-air interface. Journal of Geophysical Research, 79(33), 5025.

Eddy, C. A., Looney, B. B., Dougherty, J. M., Hazen, T. C., and Kaback, D. S. (1991) Characterization of the Geology, Gea hemistry, Hydrology and Microbiology of the In-situ Air stripping Demonstration Site at the Savannah River Site. Westinghouse Savannah River Company, WSRC-RD-9121.

Forbes, J., Havlena, J., Burkhard, M., and Myers, K. (1993) Monitoring of VOCs in deep vadose zone using multi-port soil gas wells and multi-port soil gas / ground water wells. Proc. of Seventh National Outdoor Action Conference.

Garbesi, K., Sextro, R., Fisk, W. J., Modera, M. P., and Revzan, K. L. (1993) Soil-gas entry into an experimental basement: model measurement comparisons and seasonal effects. Environmental Science and Technology, 27, 466.

Kaback, D. S., Looney, B. B., Eddy, C. A., and Hazen, T. C. (1991) Innovative ground water and soil remediation: In situ air stripping using horizontal wells. Proc. of Fifth National Outdoor Action Conference. 
Little, J. C., Daisey, J. M., and Nazaroff, W. W. (1992) Transport of subsurface contaminants into buildings. Environmental Science and Technology, 26(11), 2058.

Looney, B. B. (1992) Assessing DNAPL Contamination, A/M Area, Savannah River Site: Phase I Results. Westinghouse Savannah River Company, WSRC-RP-92-1302.

Massman, J. and Farrier, D. F. (1992) Effects of atmospheric pressures on gas transport in the vadose zone. Water Resources Research, 28(3), 777.

Narasimhan, T. N., Tsang, Y. W., and Holman, H. Y. (1990) On the potential importance of transient air flow in advective Radon entry into buildings. Geophysical Research Letters, 17(6), 821.

Nilson, R. H., Peterson, E. W., Lie, K. H., Burkhard, N. R., and Hearst, J. R. (1991) Atmospheric pumping: a mechanism causing vertical transport of contaminated gases through fractured permeable media. Journal of Geophysical Research, 96(B13), 21933.

Owczarski, P. C., Holford, D. J., Freeman, H. D., and Gee, G. W. (1990) Effects of changing water content and atmospheric pressure on radon flux from surfaces of five soil types. Geophysical Research Letters, 17(6), 817.

Peck, A. J. (1960) The water table as affected by atmospheric pressure. Geophysical Research, 65(8), 2383.

Pirkle, R. J., Wyatt, D. E., Price, V., and Looney, B. B. (1992) Barometric pumping: the connection between the vadose zone and the atmosphere. The Focus Eastern Regional Ground Water Issues Conference.

Ritzi Jr., R. W., Sorooshian, S., and Hsieh, P. A. (1991) The estimation of fluid flow properties from the response of water levels in wells to the combined atmospheric and earth tide forces. Water Resources Research, 27(5), 883.

Rohay, V. J., and Cameron, R. J. (1992) Field measurements of natural soil-gas venting cycles in boreholes at the Hanford Site, Washington. Eos Transactions, American Geophysical Union 1992 Fall Meeting, 73(43), 238.

Rojstaczer, S., and Riley, F. S. (1990) Response of the water level in a well to earth tides and atmospheric loading under unconfined conditions. Water Resources Research, 26(8), 1803.

Rojstaczer, S. (1988) Determination of fluid flow properties from the response of water levels in wells to atmospheric loading. Water Resources Research, 24(11), 1927.

Rossabi, J., Looney, B. B., Riha, B., Ferrelli, A., and Smith, N. (1992) The Influence of Surface Pressure Fluctuations on Surface/Subsurface Air Migration, Eos Transactions, American Geophysica Union 1992 Fall Meeting 73(43), 233. 
Sleep, B. E., and Sykes, J. F. (1989) Modeling the transport of volatile organics in variably saturated media. Water Resources Research, 25(1), 81.

Tsang, Y. W., and Narasimhan, T. N. (1992) Effects of periodic atmospheric pressure variation on Radon entry into buildings. Journal of Geophysical Research, 97(B6), 9161.

Weber, D., and Schwille, F. (1991) Passive vapor monitoring of underground storage tanks for leak detection. Environmental Monitoring and Assessment, 16, 99.

Weeks, E. P. (1978) Field determination of vertical permeability to air in the unsaturated zone. Geological Survey Professional Paper 1051.

Weeks, E. P. (1979) Barometric fluctuations in well tapping deep unconfined aquifers. Water Resources Research, 15(5), 1167. 


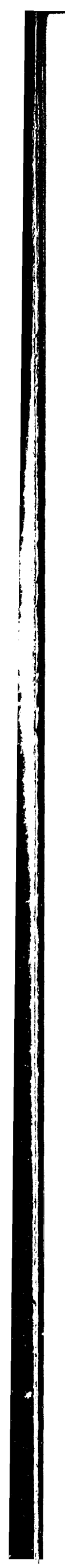

